\title{
The most common health care services needed by university students and employees
}

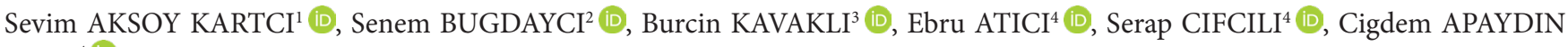 \\ $\mathrm{KAYA}^{4}$ (D) \\ Kocaeli Basiskele Yuvacik Serdar Family Health Center, Kocaeli, Turkey. \\ Pendik 9th Family Health Center, Pendik, Istanbul, Turkey. \\ Kocaeli Halil Ibrahim Alemdar Family Health Center, Kocaeli, Turkey. \\ 4 Department of Family Medicine, School of Medicine, Marmara University, Istanbul, Turkey. \\ Corresponding Author: Cigdem APAYDIN KAYA \\ E-mail: cigdemapaydin@yahoo.com
}

Submitted: $15.09 .2019 \quad$ Accepted: 02.11.2019

\begin{abstract}
Objectives: The identification of the health needs of university students and staff may be the first step in improving public health approaches. The aim of this study was to investigate the most needed health care services by the university students and employees. Materials and Methods: A cross-sectional study was carried out with 864 representative individuals on Marmara University Göztepe Campus, Istanbul, Turkey. All participants were given a questionnaire including questions about the sociodemographic characteristics and health status, healthy lifestyle behaviours and health needs.

Results: The mean age of the participants was $24 \pm 7.9$ years. The number of participants who had periodic health maintenance/ check-up was $11.4 \%$. Smoking and alcohol use prevalence was similar for students and employees (30.9\% and 30.2\%). Depression screening was found to be positive in $67.4 \%$ of the participants ( $58.7 \%$ of the employees, $69.7 \%$ of the students).The most commonly requested information was on healthy nutrition (42.4\%), followed by screening for diseases (32.3\%), emergency situations/first aid (31.2\%), exercise counselling (28.6\%) and prevention of chronic diseases $(27.8 \%)$.

Conclusion: Our findings show that the most needed health care services are psychological counselling, periodic health controls, health promotion counselling and first aid training.

Keywords: Prevention and control, Primary health care, Occupational health, Depression
\end{abstract}

\section{INTRODUCTION}

In the World Health Organization's reports, "the needs and expectations of individuals and society should be met" is emphasized as one of the main features of the health systems [1]. In order to meet the health needs and expectations of populations, the needs should be determined first. An assessment of health needs provides the opportunity to review the health problems society faces and to identify and solve the new health issues. At the same time, by giving service providers an idea about how to define priorities, such an assessment offers an additional opportunity to achieve the effective use of resources and reduce inequalities in health service delivery [2]. The assessment of health needs is useful for health care planners in terms of evaluating the changing health parameters of the population [2]. When the needs and expectations of health care recipients are reviewed, it is also ensured that service recipients participate in the decisionmaking process [2]. Participation in decision-making processes is one of the characteristics that a quality health service should have. Although, the provision of rare and expensive services has been perceived as a mark of high quality in the past, nowadays, meeting the expectations and needs of the health care recipient is defined as a quality indicator $[3,4]$. Therefore, taking patient views into consideration is increasingly becoming of great importance in the evaluation of services and in ensuring service continuity.

Most researches conducted on the university campuses related to expected and offered health services focus only on students [5, 6]. Knowing the health needs of young university students, the competent adults of the future, is important in terms of planning the initiatives to protect and promote the health of individuals and the community. However, there are also academicians and other employees working at the universities, and there are only limited research available on the health needs and expectations of these groups [7]. In Turkey, units called "Medico-Social" or "Health Counseling" Centers have been organized to provide primary health care services for students and employees on university campuses. After the government's Reorganization of Primary Care, some

How to cite this article: Aksoy Kartci S, Bugdayci S, Kavakli B, Atici E, Cifcili S, Apaydin Kaya C. The most common health care services needed by the university students and employees. Marmara Med J 2020;33: 27-34 doi: 10.5472/marumj.681967 
Medico-Social Centers in Turkey were transformed into Family Medicine Centers, but some continue to serve actively, providing services under the same name and conditions as on Marmara University Goztepe Campus. It has been observed, however, that the number of physicians employed in these health centers is quite low when compared to the entire campus population. So, an assessment of the health needs of students and employees in a university is of vital importance in terms of determining the content and priorities of health service delivery.

The aim of this study was to investigate the most needed health care services by university students and employees.

\section{MATERIALS and METHODS}

Our research is a descriptive cross-sectional study that was conducted between January 1, 2016 and February 10, 2016. The population of the study consisted of students enrolled in daytime education and employees working at Marmara University Göztepe Campus. According to the information received from the Rectorate of Marmara University, the total number of these groups stood at 29,575 on the date of the survey. Out of this, $93.61 \%$ were students $(n=27,684), 6.39 \%$ were employees $(n=1,891)$. The academic staff among the employees constituted $3.95 \%$ of the entire population ( $\mathrm{n}=1,167)$; those who work in administrative or service jobs represented $2.44 \%(n=724)$. These figures show that the population of Marmara University Göztepe Campus is greater than most university and residential populations in Turkey.

The number of samples targeted was calculated to be 652 individuals at a $99 \%$ confidence interval and a $5 \%$ margin of error. It was predicted that $20 \%$ of the data collection form would not be filled out, and it was planned that 782 individuals would be reached.

Seventeen units (faculties and academies, administrative units, libraries, etc.) on campus were evaluated as strata and the proportional stratified sampling method was used in order to reach the sampling that would reflect the students and staff in each stratum. The subunits in each stratum were determined by drawing lots. If a subunit was not suitable for the survey, an alternative unit was chosen by re-drawing. In the subunits determined, a re-draw determined which class of students was to be sampled.

The drawing process was repeated until the sample size reached the determined number for that stratum. In each stratum, an attempt was made to reach the number of students / employees according to their ratio in the universe. Permission for the students' participation was obtained from the head of the departments and the lecturers responsible for the course, and a questionnaire was administered in the classes on a voluntary basis. Due to the low number of academic and administrative staff in the sampling ( $6.4 \%$ of the sample: $782 \times 6.4 / 100=50$ persons), the researchers planned to collect data from all willing workers who were present on the day of the visit paid to the unit chosen at the drawing.

The inclusion criteria were as below:

- Voluntary participation in the study

- Being enrolled in daytime education, for students

- Being on the staff of Marmara University Göztepe Campus, for employees
- Have no problems with language comprehension and expression (spoken and written)

Those who left more than half of the questionnaire empty were excluded from the study.

\section{Data collection tools}

The participants were asked to respond to a self-administered questionnaire that included questions on sociodemographic characteristics such as age, sex, marital status, place of residence, social security, and household monthly income, as well as questions evaluating health status [current diseases, medications, prescription or over-the-counter medications, thoughts about weight problems, health perception, the utilization of health services and the accessibility of certain preventive health services (frequency of doctor visits in the past year, health institutions, periodic examinations or check-up, cancer and other health screening), and healthy lifestyle behaviors (being on a diet for weight loss, exercise frequency, fast food consumption, number of meals, smoking, alcohol use, prevention of sexually transmitted diseases (STD)] and their expectations and needs from a primary health center. In addition, questions on health needs and expectations were openended, and similar answers were grouped under one heading.

The perception of general health was evaluated on a 5-point Likert scale, ranging from "very good" to "very bad." A 2-item short depression screening test was used for depression screening $[8,9]$. Those who answered "Yes" to any of the questions were evaluated as "positive" in terms of depression screening. This short test, also called the Whooley Questions, has a sensitivity of $0.96(0.89-0.98)$ and a specificity of 0.57 (0.52-0.61) [9]. Also, women were queried on any history of unplanned pregnancies.

This study was approved by the Marmara University, School of Medicine Ethics Committee (approval number: 002). The participants who met the inclusion criteria were informed about the study and their consents were obtained.

\section{Statistical analysis}

The Statistical Package for Social Sciences (SPSS) 16 computer package program was used to evaluate the data. Categorical variables were compared with the chi-square or Fisher test, and continuous variables were compared with the independent Student's t-test. When parametric test hypotheses were not met, non-parametric equivalents of these tests were used. The value $\mathrm{p}<0.05$ was considered statistically significant.

\section{RESULTS}

\section{Sociodemographic characteristics of the participants}

A total of 864 people, 505 women (58.4\%) and 359 men (41.6\%), who completed more than half of the questionnaire participated in the research. The average age of the participants was $24 \pm 7.9$ years (min:18-max:68). Of the participants $(n=696), 80.5 \%$ were students, $8.8 \%(n=76)$ were academicians, $10.7 \%(n=92)$ were administrative or service personnel.

The sociodemographic characteristics of all participants are shown in Table I. 
Table I. Sociodemographic characteristics of the participants

\begin{tabular}{|c|c|c|c|c|}
\hline & $\begin{array}{l}\text { Students } \\
\mathrm{n}=696\end{array}$ & $\begin{array}{l}\text { Academic } \\
\text { Staff } \\
\mathrm{n}=76\end{array}$ & $\begin{array}{l}\text { Other Staff } \\
\mathrm{n}=92\end{array}$ & $\begin{array}{l}\text { Total } \\
\mathrm{n}=864\end{array}$ \\
\hline \multicolumn{5}{|l|}{ Age } \\
\hline Mean \pm SD & $20.9 \pm 2.5$ & $35.4 \pm 9.2$ & $38.8 \pm 9.6$ & $24 \pm 7.9$ \\
\hline $\begin{array}{l}\text { Median (Min- } \\
\text { Max) }\end{array}$ & $21(18-50)$ & $33(23-68)$ & $38(20-59)$ & $21(18-68)$ \\
\hline \multicolumn{5}{|l|}{ Marital status } \\
\hline Married & $17(2.5 \%)$ & $42(55.3 \%)$ & $58(64.5 \%)$ & $117(13.7 \%)$ \\
\hline Single & $671(97.1 \%)$ & $34(44.7 \%)$ & $30(33.3 \%)$ & $735(85.7 \%)$ \\
\hline Widow & $\begin{array}{l}3(0.4 \%) \\
n=690\end{array}$ & $\begin{array}{l}- \\
\mathrm{n}=76\end{array}$ & $\begin{array}{l}2(2.2 \%) \\
\mathrm{n}=90\end{array}$ & $\begin{array}{l}5(0.6 \%) \\
n=857\end{array}$ \\
\hline \multicolumn{5}{|l|}{ Education } \\
\hline $\begin{array}{l}\text { Middle school } \\
\text { and lower }\end{array}$ & - & - & $7(7.6 \%)$ & $9(1.0 \%)$ \\
\hline High School & $686(98.6 \%)$ & - & $14(15.2 \%)$ & $740(85.7 \%)$ \\
\hline University & - & $4(5.2 \%)$ & $62(67.4 \%)$ & $25(2.9 \%)$ \\
\hline \multirow{2}{*}{$\begin{array}{l}\text { Post-graduate } \\
\text { degree }\end{array}$} & $10(1.4 \%)$ & $72(94.8 \%)$ & $9(9.8 \%)$ & $90(10.4 \%)$ \\
\hline & $\mathrm{n}=696$ & $\mathrm{n}=76$ & $\mathrm{n}=92$ & $\mathrm{n}=864$ \\
\hline \multicolumn{5}{|l|}{$\begin{array}{l}\text { Residence } \\
\text { (longest lived) }\end{array}$} \\
\hline City & $560(81.5 \%)$ & $66(86.8 \%)$ & $80(87.9 \%)$ & $706(82.7 \%)$ \\
\hline Town & $81(11.8 \%)$ & $9(11.8 \%)$ & $7(7.7 \%)$ & $97(11.3 \%)$ \\
\hline \multirow[t]{2}{*}{ Village } & $46(6.7 \%)$ & $1(1.3 \%)$ & $4(4.4 \%)$ & $51(6.0 \%)$ \\
\hline & $\mathrm{n}=687$ & $\mathrm{n}=76$ & $\mathrm{n}=91$ & $\mathrm{n}=854$ \\
\hline \multicolumn{5}{|l|}{$\begin{array}{l}\text { Place of } \\
\text { residence }\end{array}$} \\
\hline House & $549(82.2 \%)$ & $75(100 \%)$ & $84(91.3 \%)$ & $708(85.6 \%)$ \\
\hline Private dorm & $64(9.6 \%)$ & - & - & $64(7.7 \%)$ \\
\hline State dorm & $47(7.0 \%)$ & - & - & 47 (557\%) \\
\hline \multirow[t]{2}{*}{ Other } & $8(1.2 \%)$ & - & - & $8(1.0 \%)$ \\
\hline & $\mathrm{n}=668$ & $\mathrm{n}=75$ & $\mathrm{n}=84$ & $\mathrm{n}=827$ \\
\hline \multicolumn{5}{|l|}{ Reside with } \\
\hline Alone & $369(53.9 \%)$ & $11(14.7 \%)$ & $6(6.7 \%)$ & $71(8.3 \%)$ \\
\hline Family & $154(22.5 \%)$ & $13(17.3 \%)$ & $18(20.0 \%)$ & $400(47.0 \%)$ \\
\hline Friends & $93(13.5 \%)$ & $6(8.0 \%)$ & $5(5.6 \%)$ & $165(19.4 \%)$ \\
\hline Spouse & $54(7.9 \%)$ & $15(20.0 \%)$ & $10(11.1 \%)$ & $36(4.2 \%)$ \\
\hline $\begin{array}{l}\text { Spouse and } \\
\text { children }\end{array}$ & $11(1.6 \%)$ & $27(36.0 \%)$ & $46(51.1 \%)$ & $78(9.2 \%)$ \\
\hline \multirow[t]{2}{*}{ Other* } & $4(0.6 \%)$ & $3(4.0 \%)$ & $5(5.5 \%)$ & $101(11.9 \%)$ \\
\hline & $\mathrm{n}=685$ & $\mathrm{n}=77$ & $\mathrm{n}=90$ & $\mathrm{n}=851$ \\
\hline \multicolumn{5}{|c|}{ Social insurance } \\
\hline Yes & $538(79.1 \%)$ & $74(98.7 \%)$ & $90(98.9 \%)$ & $704(83.15)$ \\
\hline \multirow[t]{2}{*}{ No } & $142(20.9 \%)$ & $1(1.3 \%)$ & $1(1.1 \%)$ & $143(16.9 \%)$ \\
\hline & $\mathrm{n}=680$ & $\mathrm{n}=75$ & $\mathrm{n}=91$ & $\mathrm{n}=847$ \\
\hline \multicolumn{5}{|l|}{$\begin{array}{l}\text { Perception of } \\
\text { income }\end{array}$} \\
\hline Low & $390(56.9 \%)$ & $1(1.3 \%)$ & $63(69.2 \%)$ & $99(11.6 \%)$ \\
\hline Moderate & $196(28.6 \%)$ & $35(46.7 \%)$ & $14(15.4 \%)$ & $489(57.3 \%)$ \\
\hline Good & $15(2.2 \%)$ & $37(49.3 \%)$ & $13(14.3 \%)$ & 247 (29.0\%) \\
\hline \multirow[t]{2}{*}{ Very good } & $85(12.4 \%)$ & $2(2.7 \%)$ & $1(1.1 \%)$ & $18(2.1 \%)$ \\
\hline & $\mathrm{n}=686$ & $\mathrm{n}=75$ & $\mathrm{n}=91$ & $\mathrm{n}=853$ \\
\hline
\end{tabular}

Percentages were calculated for the respondents of each group

* Other: siblings, relatives, etc.

\section{Health status of the participants}

The data on the health status of the voluntary participants in the study are shown in Table II. Accordingly, it was seen that approximately more than half of the participants (59.2\%) had no known disease, while the three most common diseases were anemia (9.6\%), allergic rhinitis (7.6\%), and asthma (4.2\%). The number of individuals who had diseases was greater among the staff rather than the students. Of the participants, $68.8 \%$ described their general health status as "good" or "very good". Fifteen participants $(1.9 \%)$ declared that they had a physical disability and 4 of them reported their physical disability as being advanced myopia and visual impairment.

Table II. Health status of the participants

\begin{tabular}{|c|c|c|c|c|}
\hline & $\begin{array}{l}\text { Total } \\
\mathrm{n}=864\end{array}$ & $\begin{array}{l}\text { Students } \\
\mathrm{n}=696\end{array}$ & $\begin{array}{l}\text { Staff } \\
n=168\end{array}$ & p \\
\hline $\begin{array}{l}\text { Any disease }(\mathrm{n}= \\
701)\end{array}$ & $\mathrm{n}(\%)$ & $\mathrm{n}(\%)$ & $\mathrm{n}(\%)$ & \\
\hline No & $415(59.2 \%)$ & $355(63.6 \%)$ & $60(42.0 \%)$ & $\mathrm{N} / \mathrm{S}$ \\
\hline Yes & $286(40.8 \%)$ & $203(36.4 \%)$ & $83(58.0 \%)$ & $<0.001$ \\
\hline $\begin{array}{l}\text { Physical disability } \\
(\mathrm{n}=791)\end{array}$ & $15(1.9 \%)$ & $11(1.8 \%)$ & $4(2.4 \%)$ & $\mathrm{N} / \mathrm{S}$ \\
\hline \multicolumn{5}{|l|}{$\begin{array}{l}\text { General health } \\
\text { perception }(n=784)\end{array}$} \\
\hline Good-Very good & $539(68.8 \%)$ & $444(69.5 \%)$ & $95(65.5 \%)$ & $\mathrm{N} / \mathrm{S}$ \\
\hline Moderate & $233(29.7 \%)$ & $186(29.1 \%)$ & $47(32.4 \%)$ & $\mathrm{N} / \mathrm{S}$ \\
\hline Bad-Very bad & $12(1.5 \%)$ & $9(1.4 \%)$ & $3(2.1 \%)$ & $\mathrm{N} / \mathrm{S}$ \\
\hline $\begin{array}{l}\text { Prescribed } \\
\text { medication use } \\
(\mathrm{n}=846)\end{array}$ & $110(13 . \%)$ & $69(10.1)$ & $41(25.0 \%)$ & $<0.001$ \\
\hline $\begin{array}{l}\text { Over-the-counter } \\
\text { medication use } \\
(\mathrm{n}=830)\end{array}$ & $256(30.8 \%)$ & $198(29.6)$ & $58(35.8)$ & $\mathrm{N} / \mathrm{S}$ \\
\hline $\begin{array}{l}\text { Self-perceived } \\
\text { weight status } \\
(\mathrm{n}=801)\end{array}$ & $257(32.1 \%)$ & $184(29.0)$ & $73(44.0)$ & $<0.001$ \\
\hline $\begin{array}{l}\text { Positive for } \\
\text { depression } \\
\text { screening }(n=814)\end{array}$ & $549(67.4 \%)$ & $451(69.7 \%)$ & $98(58.7 \%)$ & $\mathrm{p}=0.007$ \\
\hline
\end{tabular}

Percentages were calculated for the respondents of each group.

Among the responders, $(\mathrm{n}=814) 67.4 \%(\mathrm{n}=549)$ responded positively to at least one question of the two-item depression screening questions. Depression screening was found to be positive in $74.6 \%$ of the women $(\mathrm{n}=350)$ and in $58.9 \%$ of the men $(\mathrm{n}=199)(\mathrm{p}<0.001)$.

The frequency of regularly taking at least one prescribed medication was $13 \%$ and this frequency was more common among women than men $(16.0 \%, 8.9 \% ; \mathrm{p}=0.003)$. Among the employees, the number of those who regularly took prescribed medications was more than the number of the students $(25.0 \%$, $10.1 \% ; \mathrm{p}<0.001$ ). Those who were reported to be taking at least one over-the-counter medication in the last year represented $30.8 \%$ and the majority of these over-the-counter medications were pain killers and cold/flu drugs. 
The frequency of the participants' thinking that they had a weight problem was $32.1 \%$ and $13.4 \%$ were on a special weight loss diet. While there was no significant difference with regard to gender among those who thought that they had a weight problem, the frequency of following a weight loss diet among the women was significantly higher than among the men $(17.2 \%, 8.2 \% ; \mathrm{p}<0.001)$. Among the employees, the number of those who thought that they had weight problems was greater than the number of students $(44.0 \%, 29.0 \%$; $\mathrm{p}<0.001)$.

\section{Utilizing some health services}

Of the participants, $18.2 \%$ reported that they had never applied to a doctor for any reason in the last one year. Among the applicants, the average number of applications to the doctor in the last year was $3.2 \pm 3.1$ (median: 2 ; min 1-max 30; IQR 1-3). The frequency was higher among the women than the men (3.06 \pm 3.38 for women; median $=2$; IQR: 1 -4; for men $2.08 \pm 2.42$, median=2; IQR:1-3; $<<0.001$ ).

The most frequently utilized health institutions are public hospitals at a rate of $63.2 \%$, family health centers at $40.5 \%$ and private hospitals at $33 \%$. The frequency of applicants who applied to a Family Physician for any reason in the last 1 year was $71.4 \%$, and this rate is higher among women than men $(75.9 \% ; 64.8 \% ; p=0.001)$. The frequency of those who previously obtained services from the Medico-Social Center of the University was $37.4 \%$. Of those who were obtaining service from the Medico-Social Center, 58\% stated that they were "satisfied" or "very satisfied" with the service they received. Among the employees, the number of those who obtained services from the medico-social health center were greater than the number of students $(85.5 \%, 24.9 \%$; $\mathrm{p}<0.001)$. Among those who did not receive any service from the Medico-Social centers $(n=183)$, in responding to the open-ended question asking why they did not receive any services, $94.53 \%(n=173)$ stated that they did not need it, or they had no information about the services provided; 10 individuals (5.47\%) reported that they were not satisfied with the services they received and did not use the medico-social center because they felt insecure there.

Table III shows situations in which some preventive health care had been previously obtained. The number of people who declared that they had periodic health maintenance or check-ups and had no previous complaint represented $11.4 \%$ $(\mathrm{n}=92)$ and this rate was higher in women $(13.5 \%)$ than the rate of men $(8.6 \%)(p=0.033)$. Among the employees, the number of those who had periodic controls/check-ups was greater than the number of students $(24.6 \%, 8.0 \%$; $<<0.001)$. To the open-ended question about "check-up content," the participants' most common responses were blood tests, eye examinations, cardiology examinations, and breast examination. The most frequently reported scans performed were blood pressure $(30.1 \%)$ and fasting glucose control $(27.3 \%)$. There were some significant differences between the participants' scans performed when compared by gender, namely that more women than men reported that they had cholesterol, blood pressure and fasting glucose checkups ( $\mathrm{p}=0.002 ; \mathrm{p}=0.001 ; \mathrm{p}=0.000$, respectively). Among women over the age of 40 , the frequency rate of mammogram screening was $65 \%$.

Table III. Some preventive health services previously received

\begin{tabular}{lcc} 
& n & $\%$ \\
\hline $\begin{array}{l}\text { Periodic health maintenance or check- } \\
\text { ups }\end{array}$ & 92 & 11.4 \\
\hline Screenings & 260 & $30.1^{\mathrm{a}}$ \\
\hline Blood pressure measurement & 236 & $27.3^{\mathrm{a}}$ \\
Blood glucose measurement & 95 & $11.0^{\mathrm{a}}$ \\
Cholesterol measurement & 28 & $31.5^{\mathrm{b}}$ \\
Pap smear & 26 & $65.0^{\mathrm{c}}$ \\
Mammogram & 1 & $4.3^{\mathrm{d}}$ \\
Fecal occult blood test & 4 & $17.4^{\mathrm{d}}$ \\
Colonoscopy & 0 & $0.0^{\mathrm{e}}$ \\
Prostate examination & 56 & $6.5^{\mathrm{f}}$ \\
\hline Other blood tests & & \\
\hline
\end{tabular}

a: For all participants, b: For women $>35$ years old ( $n=89$ ), c: For women $\geq 40$ years old $(n=40)$, d: For women $>50$ years old $(n=23)$, e: For $m e n \geq 50$ years old $(\mathrm{n}=23)$, f: Other blood tests: vitamin level, etc.

\section{Data on lifestyle behaviors}

The frequency of participants engaging in physical activity 3 times a week or more was $27.7 \%$. When compared by gender, men $(37.2 \%)$ performed physical activity more frequently than women $(26.4 \%)(p=.006)$ (Table IV). In the question about which physical activity the participants engaged in regularly, the 3 most frequent responses were "fitness (gym sports)," "team sports" (e.g., football, basketball, volleyball) and "walking/ running."

Of the participants, $30.9 \%$ reported that they smoke sometimes or every day, $30.2 \%$ are alcohol users and $4.5 \%$ have tried drugs/ stimulants. The prevalence of smoking, alcohol and drug use among men was higher than among women $(36.6 \%, 26.8 \%, \mathrm{p}=$ $0.002 ; 35.6 \%, 26.5 \%, \mathrm{p}=0.006 ; 7.7 \%, 2.3 \% ; \mathrm{p}<0.001)$. There was no statistically significant difference in the frequency of physical activity, smoking, alcohol and drug use and consuming fast food and missing meals among staff and students.

The most skipped meals of the research group were breakfast $(35.1 \%)$ and snacks $(34.8 \%)$, and $56.3 \%$ reported consuming fast food once or more a week (Table IV). 
Table IV. Lifestyles of the participants

\begin{tabular}{|c|c|c|c|c|c|c|c|}
\hline & \multicolumn{2}{|c|}{ Total } & \multicolumn{2}{|c|}{ Students } & \multicolumn{2}{|c|}{ Staff } & \multirow[t]{2}{*}{$\mathrm{p}$} \\
\hline & $\mathrm{n}$ & $\%$ & $\mathrm{n}$ & $\%$ & $\mathrm{n}$ & $\%$ & \\
\hline \multicolumn{7}{|l|}{$\begin{array}{l}\text { Frequency } \\
\text { of physical } \\
\text { activity }\end{array}$} & \multirow{6}{*}{$\mathrm{N} / \mathrm{S}$} \\
\hline $\begin{array}{l}1-2 \text { per } \\
\text { week }\end{array}$ & 228 & 38.1 & 196 & 39.0 & 32 & 33.0 & \\
\hline $\begin{array}{l}<1 \text { per } \\
\text { week }\end{array}$ & 205 & 34.3 & 161 & 32.1 & 44 & 45.4 & \\
\hline $\begin{array}{l}\geq 3 \text { per } \\
\text { week }\end{array}$ & 109 & 18.2 & 90 & 17.9 & 19 & 19.6 & \\
\hline \multirow[t]{2}{*}{ Everyday } & 57 & 9.5 & 55 & 11.0 & 2 & 2.1 & \\
\hline & $\mathrm{n}=599$ & & $\mathrm{n}=502$ & & $\mathrm{n}=97$ & & \\
\hline \multirow[t]{2}{*}{ Smokers* } & 257 & 30.9 & 209 & 31.2 & 48 & 29.3 & \multirow{2}{*}{$\mathrm{N} / \mathrm{S}$} \\
\hline & $\mathrm{n}=833$ & & $\mathrm{n}=669$ & & $\mathrm{n}=164$ & & \\
\hline \multirow[t]{2}{*}{$\begin{array}{l}\text { Alcohol } \\
\text { users }^{\star}\end{array}$} & 242 & 30.2 & 197 & 30.8 & 45 & 28.0 & \multirow{2}{*}{$\mathrm{N} / \mathrm{S}$} \\
\hline & $\mathrm{n}=801$ & & $\mathrm{n}=640$ & & $\mathrm{n}=161$ & & \\
\hline \multirow[t]{2}{*}{$\begin{array}{l}\text { Drug } \\
\text { users }^{\star}\end{array}$} & 37 & 4.5 & 33 & 5.0 & 4 & 2.5 & \\
\hline & $\mathrm{n}=820$ & & $\mathrm{n}=658$ & & $\mathrm{n}=162$ & & \\
\hline \multirow{2}{*}{$\begin{array}{l}\text { On diet } \\
\text { to reduce } \\
\text { weight }\end{array}$} & 106 & 13.4 & 80 & 12.7 & 26 & 16.1 & \\
\hline & $\mathrm{n}=791$ & & $\mathrm{n}=630$ & & $\mathrm{n}=161$ & & \\
\hline $\begin{array}{l}\text { Frequency } \\
\text { of } \\
\text { consuming } \\
\text { fast food }\end{array}$ & 52 & 6.6 & 24 & 3.8 & 28 & 17.1 & \multirow{7}{*}{$\mathrm{N} / \mathrm{S}$} \\
\hline Never & & & & & & & \\
\hline Rarely & 346 & 43.7 & 252 & 40.1 & 94 & 57.3 & \\
\hline 1 per week & 202 & 25.5 & 170 & 27.1 & 32 & 19.5 & \\
\hline $\begin{array}{l}3-4 \text { per } \\
\text { week }\end{array}$ & 141 & 17.8 & 132 & 21.0 & 9 & 5.5 & \\
\hline \multirow[t]{2}{*}{ Everyday } & 51 & 6.4 & 50 & 8.0 & 1 & 0.6 & \\
\hline & $\mathrm{n}=792$ & & $\mathrm{n}=628$ & & $\mathrm{n}=164$ & & \\
\hline \multicolumn{7}{|l|}{$\begin{array}{l}\text { Missing } \\
\text { meals }\end{array}$} & \multirow{7}{*}{$\mathrm{N} / \mathrm{S}$} \\
\hline Breakfast & 303 & 35.1 & 267 & 38.4 & 36 & 28.9 & \\
\hline Lunch & 161 & 18.6 & 131 & 18.9 & 30 & 22.4 & \\
\hline Dinner & 46 & 5.4 & 39 & 5.6 & 7 & 2.6 & \\
\hline Snacks & 301 & 34.8 & 240 & 34.5 & 61 & 42.1 & \\
\hline \multirow[t]{2}{*}{ None } & 143 & 16.6 & 88 & 12.7 & 55 & 23.7 & \\
\hline & & & $\mathrm{n}=641$ & & $\mathrm{n}=166$ & & \\
\hline
\end{tabular}

*: Every day or sometimes

\section{Expectations and needs regarding Primary Health Care}

The subjects that the participants wanted to know regarding their own health are shown in Table V. The subjects that the participants wanted to have information mostly were healthy nutrition (42.4\%), screening for diseases (32.3\%), emergency situations/first aid (31.2\%), exercise counselling (28.6\%), prevention from chronic diseases $(27.8 \%)$, respectively. The number of staff, who wanted to have information on health problems of family members, management of current chronic diseases, screening for diseases, protection against chronic diseases, emergency case/first aid, were higher than the number of students $(p=0.006, p=0.006, p<0.001, p=0.001$, $\mathrm{p}=0.001$, respectively). When compared according to gender, the information on disease screening, exercise counselling, contraception, healthy nutrition, emergency situations/first aid were more demanded by women $(\mathrm{p}=0.004, \mathrm{p}<0.001, \mathrm{p}=0.03, \mathrm{p}$ $=0.002, \mathrm{p}=0.001$, respectively).

Table V. The subjects that the participants wanted to know regarding their own health

\begin{tabular}{|c|c|c|c|c|c|}
\hline & $\begin{array}{l}\text { Total } \\
\mathrm{n}\end{array}$ & $\%$ & Students & Staff & $\mathrm{p}$ \\
\hline Healthy nutrition & 366 & 42.4 & $42.1 \%$ & $43.5 \%$ & $\mathrm{~N} / \mathrm{S}$ \\
\hline Screening for diseases & 279 & 32.3 & $28.2 \%$ & $48.8 \%$ & $<0.001$ \\
\hline Emergency case/first aid & 270 & 31.2 & $28.6 \%$ & $42.3 \%$ & 0.001 \\
\hline Exercise counselling & 247 & 28.6 & $28.7 \%$ & $28.0 \%$ & $\mathrm{~N} / \mathrm{S}$ \\
\hline $\begin{array}{l}\text { Protection against chronic } \\
\text { diseases }\end{array}$ & 240 & 27.8 & $25.0 \%$ & $37.5 \%$ & 0.001 \\
\hline $\begin{array}{l}\text { Prevention of } \\
\text { communicable diseases }\end{array}$ & 151 & 17.5 & $16.2 \%$ & $22.6 \%$ & $\mathrm{~N} / \mathrm{S}$ \\
\hline $\begin{array}{l}\text { Health problems of family } \\
\text { members }\end{array}$ & 118 & 13.7 & $10.2 \%$ & $17.9 \%$ & 0.006 \\
\hline $\begin{array}{l}\text { Management of chronic } \\
\text { diseases }\end{array}$ & 101 & 11.7 & $12.1 \%$ & $20.2 \%$ & 0.006 \\
\hline Family planning methods & 40 & 4.6 & $4.3 \%$ & $6 \%$ & $\mathrm{~N} / \mathrm{S}$ \\
\hline Others* & 23 & 2.7 & - & - & - \\
\hline
\end{tabular}

${ }^{\star}$ Other subjects: weight loss diet, sleep disorders, etc.

In the case of a new family health center on the campus, the services participants expect to benefit from are shown in Table VI. When compared by gender, the expectations of "counselling/education about sexually transmitted diseases," "treatment of sexually transmitted diseases," "smoking cessation counselling," "alcohol /substance abuse counseling" was more common among men than women $(\mathrm{p}=0.014, \mathrm{p}=0.026, \mathrm{p}=$ $0.019, \mathrm{p}=0.01$, respectively). However, the expectations of "wound care, dressing, injections," "psychological counselling," "sleep regulation," "exercise counseling," "nutrition counseling," "pregnancy follow-ups" and "regularly health checkups" were more common among women compared to men $(p=0.006$, $\mathrm{p}<0.001, \mathrm{p}=0.044, \mathrm{p}<0.001, \mathrm{p}<0.001, \mathrm{p}=0.017, \mathrm{p}=0.010$, respectively). 
Table VI. In the case of a new family health center on campus, the services expected by the participants

\begin{tabular}{|lllll|}
\hline Expected Services & Total & Students & Staff & $\mathrm{p}$ \\
\hline $\begin{array}{l}\text { General health } \\
\text { assessment }\end{array}$ & $454(52.55)$ & $341(49 \%)$ & $113(67.3 \%)$ & $<0.001$ \\
\hline Oral health & $391(45.3 \%)$ & $288(41.4 \%)$ & $103(61.3 \%)$ & $<0.001$ \\
\hline Nutrition counselling & $375(43.4 \%)$ & $291(41.8 \%)$ & $84(50 \%)$ & $\mathrm{N} / \mathrm{S}$ \\
\hline $\begin{array}{l}\text { Psychological } \\
\text { counselling }\end{array}$ & $360(41.7 \%)$ & $291(41.8 \%)$ & $69(41.1 \%)$ & $\mathrm{N} / \mathrm{S}$ \\
\hline Exercise counseling & $327(37.8 \%)$ & $255(36.6 \%)$ & $72(42.9 \%)$ & $\mathrm{N} / \mathrm{S}$ \\
\hline $\begin{array}{l}\text { Wound care, dressing, } \\
\text { injections }\end{array}$ & $311(36.0 \%)$ & $234(33.6 \%)$ & $77(45.8 \%)$ & 0.003 \\
\hline $\begin{array}{l}\text { Request to receive a } \\
\text { medical report }\end{array}$ & $295(34.1 \%)$ & $228(32.8 \%)$ & $67(39.9 \%)$ & $\mathrm{N} / \mathrm{S}$ \\
\hline Sleep regulation & $292(33.8 \%)$ & $240(34.5 \%)$ & $52(31 \%)$ & $\mathrm{N} / \mathrm{S}$ \\
\hline Weight management & $222(25.7 \%)$ & $165(23.7 \%)$ & $57(33.9 \%)$ & 0.007 \\
\hline Vaccination & $194(22.5 \%)$ & $141(20.3 \%)$ & $53(31.5 \%)$ & 0.002 \\
\hline $\begin{array}{l}\text { Smoking cessation } \\
\text { counselling }\end{array}$ & $188(21.8 \%)$ & $150(21.6 \%)$ & $38(22.6 \%)$ & $\mathrm{N} / \mathrm{S}$ \\
\hline $\begin{array}{l}\text { Management of new } \\
\text { onset health problems }\end{array}$ & $152(17.6 \%)$ & $115(16.5 \%)$ & $37(22 \%)$ & $\mathrm{N} / \mathrm{S}$ \\
\hline $\begin{array}{l}\text { Alcohol, and drug } \\
\text { counselling }\end{array}$ & $136(15.7 \%)$ & $117(16.8 \%)$ & $19(11.3 \%)$ & $\mathrm{N} / \mathrm{S}$ \\
\hline $\begin{array}{l}\text { Management of } \\
\text { chronic diseases }\end{array}$ & $130(15.05)$ & $92(13.2 \%)$ & $38(22.6 \%)$ & 0.002 \\
\hline $\begin{array}{l}\text { Management of family } \\
\text { members health } \\
\text { problems }\end{array}$ & $128(14.8 \%)$ & $68(9.8 \%)$ & $60(35.7 \%)$ & $<0.001$ \\
\hline $\begin{array}{l}\text { Counseling/education } \\
\text { about sexually } \\
\text { transmitted diseases }\end{array}$ & $96(11.1 \%)$ & $76(10.9 \%)$ & $20(11.9 \%)$ & $\mathrm{N} / \mathrm{S}$ \\
\hline $\begin{array}{l}\text { Family planning } \\
\text { methods }\end{array}$ & $90(10.4 \%)$ & $63(9.1 \%)$ & $27(16.1 \%)$ & 0.008 \\
\hline $\begin{array}{l}\text { Treatment of sexually } \\
\text { transmitted diseases }\end{array}$ & $81(9.4 \%)$ & $66(9.5 \%)$ & $15(8.9 \%)$ & $\mathrm{N} / \mathrm{S}$ \\
\hline Pregnancy follow-ups & $71(8.2 \%)$ & $44(6.3 \%)$ & $27(16.1 \%)$ & $<0.001$ \\
\hline Others* & $18(2.2 \%)$ & - & - & - \\
\hline Orot & & & \\
\hline
\end{tabular}

${ }^{\star}$ Other subjects: Eye examinations, solving orthopedic problems, etc.

\section{DISCUSSION}

This research is a cross-sectional study conducted to investigate the primary care health needs of students and employees working on a university campus. According to the results of the study, it was determined that the most needed service is regular health checkups, which should be carried out in order to contribute to maintaining the health of healthy individuals through screening tests, physical examinations, counselling and health education. In addition, our findings suggest that the entire study group should be evaluated especially in terms of smoking, healthy eating, obesity and depression.

According to the Ministry of Health's Health Statistics Yearbook 2016 data, the rate of daily or occasional tobacco use among individuals over 15 years of age in Turkey is 30.6\% [10]. Similarly, in our study, the prevalence of smoking was found to be $30.9 \%$ in the whole population. On the other hand, in our student group with the median age of 21, smoking prevalence was higher than in the data compiled in Turkey for the use of all tobacco products in the country's $15-24$ age group (31.3\% vs. $21.4 \%$ ). Our study, however, only evaluated cigarette smoking. Our findings suggest that smoking cessation counseling is a health service that the research group thought should be given priority. The counseling expectations about smoking stated by approximately $21.8 \%$ of the respondents also supports this belief. The fact that the use of other tobacco products other than cigarettes was not questioned is one of the limitations of our research since it is known that the use of the hookah or waterpipe is steadily increasing all over the world [11]. Another priority that should be given in counselling is the use of alcohol. This is important because the study showed that both the entire university population and approximately one-third of the student group used alcohol, and this figure is greater than the data for Turkey $(12.2 \%$ in Turkey overall and $9.3 \%$ in the younger age group) [10]. In many studies conducted at universities, the research group consists of only students and therefore, the intervention-targeted group was always young. However, the data of our study shows that employees as well as students, should be targeted for cigarette and alcohol counselling. The importance of this issue will be better understood when it is considered that adults, especially teachers, are role models for young people.

In our study, although the prevalence of chronic disease and regular use of medications was low, it is noteworthy that the use of over-the-counter drugs was high in all groups. Warnings about the use of over-the-counter medication should be one of the services that should be provided. In addition, one of the first studies in this regard should be conducted on the reasons for the prevalent use of over-the-counter medication. The fact that approximately one-third of the respondents wanted to be informed about protection against chronic diseases may be associated with the increasing incidence of chronic diseases in Turkey and all over the world, and thus with increased susceptibility to these conditions. The further demand for nutrition and exercise counselling, and the fact that blood pressure and blood glucose measurements are the most common screenings are elements that support this sensitivity. Our research suggests that interventions to protect against chronic diseases should be one of the services that should be given first priority on university campuses.

Depression is one of the most frequently reported occupational health problems [12]. Because of this, in 2010, the International Labor Organization included "stress and related diseases" in its "list of occupational diseases" and depression has been defined as being among the stress-related diseases [13]. In our study, the positive screening for depression in $67.4 \%$ of the study group suggests that there is a great need for psychological counseling and depression management. Positive screening for depression is more common in women than men. Similarly, in the study conducted by İnanç et al., $28 \%$ of the students examined at the University Health Center (Medico-Social Center) were diagnosed with depression [14]. Although, depression screening was high in the whole study group, the fact that it is higher in students than in employees may be related to increased feelings 
of hopelessness among adolescents due to the effects of factors such as academic problems and the social, cultural and economic changes experienced $[15,16]$. However, the factors that may be associated with depression were not examined since they were outside of the purpose of this research. Further research should be carried out on this subject. Whatever the reason, for prevention and successful management of negative effect of depression on success or productivity, strategies must be developed. Providing opportunities to students, the employees of the future, to acquire the skills needed to cope with stress during their university education will contribute to the prevention of stress-related occupational health problems in the future. Some universities are developing unique programs that enable highrisk students to recover on campus. More research is needed to determine how to deliver the best health care to students [17].

According to Turkey 2016 data, the prevalence of obesity in individuals 15 years of age and older is 53.9\% [10]. Approximately only one-fifth of the participants reported that they engage in physical activity 3 times or more per week. Although the research group was a young population, the fact that only a small number of people exercise regularly suggests that exercise counseling services should be planned. Furthermore, reducing sedentary behavior and increasing physical activity may promote life satisfaction, happiness and perceived health status among university student population [18].

Although an anthropometric measurement was not performed, $32.1 \%$ of the participants thought that they have a weight problem, $13.4 \%$ dieted, $43.4 \%$ asked for healthy nutrition counselling, and $37.8 \%$ wished to have exercise counseling. Such requests for counseling on these issues may facilitate the fight against obesity. Hence, the challenging obesity in the university setting can also contribute to the improvement of community health.

Although the frequency of application to a Family Physician in the last 1 year for any reason was quite high, it is worthy to note that there are many health needs and expectations not yet met. In order to meet these needs, there must be a fully equipped primary health care center and physicians who can be in close contact with both students and employees and are aware of expectations and needs on campus. On the other hand, the most common problems making it difficult to receive health services were reported as "indifference/lack of interest" and long waiting times; these issues should be considered.

It is significant that about a third of the respondents wanted to have information about emergency situations/first aid and this frequency was higher among employees than students. Considering that the campus is a workplace for both students and employees, attempts to meet this are of great importance for a healthy environment. In particular, a proactive approach would facilitate the prevention and early intervention of possible accidents during student training (e.g., prevention of accidents in the laboratory and when using devices, radiation protection).

Our research has a weak aspect as it was conducted at a single university, yet it has a strong aspect as it represents the students and employees on the Marmara University Göztepe campus, which has many faculties, institutes and units with a very large population. In addition, besides the students, the inclusion of academic and administrative staff as well as service workers in our research, is the other strong aspect of our study because similar studies in the literature, focus only on students [57]. With the inclusion of employees in the study, it was also revealed that students and employees had different health needs. This suggests that, among the preventive health services, prevention of chronic diseases, screening, health problems of family members, first aid and reproductive health services should not be ignored. Other weakness of this study is that the hazards of the participants were not asked. A research on the occupational hazards of each faculty, institution or unit in the university and the interventions may be the subject of another study. Another limitation is that fewer students than the sample required were reached. An attempt had been made at the data collection stage to reach the number of students determined in each strata constituting the sample, but the study was ultimately completed with fewer students due to the fact that in some units there were no current courses, meaning that fewer students participated and some students did not fill out more than half the questionnaire.

In summary, our findings show that psychological counselling, healthy lifestyle counselling, first aid training and periodic health controls, including prevention of diseases, screening examinations and tests, are the most needed services in the university population. Identifying the health needs of university workers and students, who will become employees of the future, may contribute to developing interventions that improve these individuals' physical and psychological health and performance.

\section{Acknowledgements}

We would like to thank $2^{\text {nd }}$ year medical school students for helping with data collection. Special thanks to Emine Mizyal for her contribution to the English editing.

\section{Compliance with Ethical Standards}

Ethical approval: The study was reviewed and approved by the Marmara University, School of Medicine Ethical Committee.

Funding: The study was not supported by any funds.

Conflict of interest: The authors declare that they have no conflict of interest.

Informed consent: The participants who met the inclusion criteria were informed about the study and their consent was obtained.

Author contributions: Conception and design of the study: CAK and SC, Acquisition of data:SKA, SB and BK, Analysis and interpretation of data: CAK, SKA and EA, Drafting of the manuscript: CAK, SKA and SC, Critical revision:: CAK and SKA.

\section{REFERENCES}

[1] World Health Organization. Health Systems: Improving performance. In: The World Health Report. Geneva: World 
Health Organization. 2000: 215. ISBN 924156198 X Available at: http://www.who.int/whr/2000/en/whr00_en.pdf?ua=1 Accessed on 28.08.2019

[2] O'Kelly CM, Cullen W, O'Kelly SM, O’Kelly FD, Bury G. A primary care based health needs assessment in inner city Dublin. Ir J Med Sci 2010;179:399-403. doi:10.1007/ s11845.010.0483-5

[3] Aydın S, Hatırlı Y. Total quality management in primary health care. Turkish Journal of Family Practice 2003;7:131-4.

[4] Starfield B, Shi L, Macinko J. Contribution of primary care to health systems and health. Milbank Q 2005;85:457-502. doi: 10.1111/j.1468-0009.2005.00409.x.

[5] Kara İH, Bahçebaşı T, Kandiş H, et al. Determination of medico-social needs, knowledge and utilization levels of Düzce university students. Konuralp Medical Journal 2009;1:7-15.

[6] Beyhun NE, Vaizoğlu SA, Çakmak F, et al. The outpatients satisfaction at two health centers of a university. TAF Preventive Medicine Bulletin 2005;4:25-36.

[7] Tapps T, Symonds M, Baghurst T. Assessing employee wellness needs at colleges and universities: A case study. Cogent Soc Sci 2016;2:1250338. doi: 10.1080/23311.886.2016.1250338.

[8] U.S Preventive Services Task Force (USPSTF). Recommendations of the U.S. Preventive Services Task Force. In: The Guide to Clinical Preventive Services 2014. U.S. Department of Health and Human Services Agency for Healthcare Research and Quality AHRQ 2014: Pub. No. 1405158. ISBN 978-1-58763-439-0. Available at: www.ahrq.gov/ sites/default/files/publications/files/cpsguide.pdf Accessed on: 30.08.209

[9] Whooley MA, Avins AL, Miranda J, Browner WS. Case-finding instruments for depression: two questions are as good as many. J Gen Intern Med 1997;12:439-45. doi: 10.1046/j.15251497.1997.00076.x.

[10] Republic of Turkey Ministry of Health. In: Health Statistics Yearbook 2016. Ankara: Ministry of Health. 2017: Pub no. 1083. Available at: https://dosyasb.saglik.gov.tr/ Eklenti/13183,sy2016turkcepdf.pdf?0 Accessed on: 30.08.2019

[11] World Health Organization. Fact sheet: waterpipe tobacco smoking and health. Available at: http://www.who.int/ tobacco/publications/prod_regulation/factsheetwaterpipe/ en/ Accessed on 30.08.2019

[12] Venables KM, Allender S. Occupational health needs of universities: a review with an emphasis on the United Kingdom. Occup Environ Med 2006;63:159-67. doi: 10.1136/ oem.2005.022145.

[13] ILO.R194 - List of Occupational Diseases Recommendation, 2002 (No. 194), revised annex 2010. Available at: http://www. ilo.org/dyn/normlex/en/f?p=1000:12100:0::NO::P12100_ ILO_CODE:R194. Accessed on: 02.09.2019

[14] İnanç N, Savaş H, Tutkun HA, Herken H, Savaş E. The clinical and sociodemographic characteristics of the students psychiatrically examined at the Medico-Social Center of Gaziantep University. Anatolian Journal of Psychiatry 2004;5:222-30.

[15] Özkürkçügil AÇ. Bir medikososyal merkezine genel sağlık sorunları ile başvuran öğrencilerden psikiyatrik tanı alanlarda bazı sosoyodemografik özellikler. Türk Psikiyatri Dergisi 1999;10:115-22.

[16] Gfellner BM, Cordoba AI. Identity problems, ego strengths, perceived stress, and adjustment during contextual changes at university. Identity 2017;17:25-39.doi: 10.1080/15283.488.2016.1268961.

[17] Morris MR, Feldpausch NI, Inga Eshelman MG, BohleFrankel BU. Recovering in place: Creating campus models of care for the high-risk college student. Curr Psychiatry Rep 2019: 19;21:111. doi: 10.1007/s11920.019.1101-5.

[18] Pengpid S, Peltzer K. Sedentary behaviour, physical activity and life satisfaction, happiness and perceived health status in university students from 24 countries. Int J Environ Res Public Health 2019;16:2084. doi:10.3390/ijerph16122084 